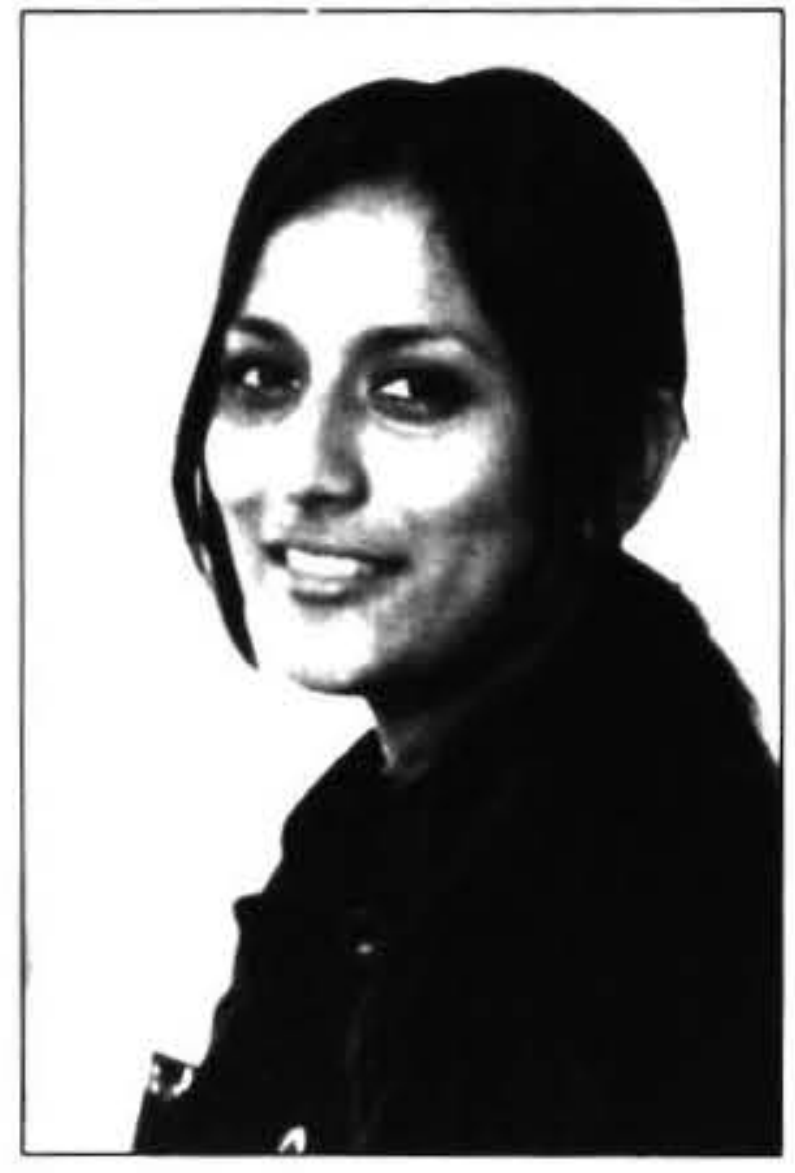

\section{STUCK FOR CHOICE? THE WORK LIFE EXPERIENCES OF MATURE-AGED WORKERS IN \\ A NEW ZEALAND CALL CENTRE}

\author{
Zeenobiyah Hannif \\ School of Management and Marketing, \\ The University of Wollongong, Australia
}

\begin{abstract}
Although there has heen a great deal written globally about the ageing population, and the potential socio-economic implications of aged workers on developed economies. only recently has attention been paid to how aged workers experience work in the new econom!: Increasingly: there is evidence to suggest mature-aged workers experience considerahle difficulties in finding work, with age discrimination becoming increasingly prevalent. This paper examines the work life experiences of 10 mature-aged workers in a New Zealand call centre: Tadco where 31 percent of the workforce comprises those in the 50 years plus age groups. Reporting on the individual accounts of aged workers in Tadco, this paper raises some contentious issues relating to the employment of aged workers, including whether mature-aged workers are filtered into precarious working conditions hecause of the lack of opportunities elsewhere, whether there is a deliherate strategy to hire mature-aged workers into low quality jobs, and what the motivations are hehind this.
\end{abstract}

\section{Introduction}

As in other developed countries, population ageing is considered one of the most significant social trends to be experienced in New Zealand. By 2051. it is projected that half of all New Zealanders will be older than 46 years. compared with the current median age of 34 years (Statistics New Zealand, 2004).

Alongside these trends has emerged a relatively underresearched area relating to the employment and working life experiences of mature-aged workers. For the purposes of this paper, the term 'mature aged-worker' refers to the employment of those in the 55 years and over age groups. Census data from 2001 indicates that a total of 261.216 workers or $14 \%$ of the total workforee is comprised of workers in these age groups (Statistics New Zealand, 2001).

Researchers and policy makers have highlighted the difficulties experienced by mature-aged workers in finding gainful employment, particularly those who have been made redundant late in their careers, and face increasing levels of age discrimination when attempting to re-enter the labour market (Ilmarinen and Rantanen, 1999: DOL. 2002: Statistics New Zealand, 2004). There is, however, little New Zealand based case study data available to understand the experiences of these workers when they do in fact re-enter the workforce. This paper draws on the working experiences of 10 mature aged workers employed in a New Zealand based call centre: Tader and types of jobs mature-aged workers undertake and how satisfied they are in these jobs?
Although the findings from this case study cannot be generalised to the mature-aged population as a whole, they do lend some insight into how mature-aged workers fare in the labour market, particularly those who are forced to re-enter or remain in the workforce because of financial considerations. Before embarking on this, this paper will firstly provide a brief examination of the literature pertaining to the employment of mature-aged workers, highlighting the gaps that need to be addressed. The methodology underlying this study will then be outlined. Finally, the experiences of the mature-aged workers will be examined and discussed.

\section{Background}

All advanced industrialised countries are facing the challenges associated with ageing populations, which can largely be attributed to increased life expectancies, declining birth rates, and baby boomers approaching the retirement age (Department of Economic and Social Affairs, 2003; Encel, 2003). Encel (2003) argues that the impact of population ageing is being further compounded by relatively low levels of labour force participation among mature-aged workers. Data derived from the 2001 New Zealand Census indicates that $53 \%$ of the total population not currently in the labour force is made up of those in the 55 years and over age groups. Again, this is a trend that is visible in all industrialized countries. The World Health Organisations (1993) suggests work force participation rates of 45 years and over age groups have been declining continuously since the 1960's. 
Lissenburgh and Smeaton (2003) suggest economic inactivity among mature-aged workers has grown as a result of people taking early retirement or from losing their jobs and getting discouraged in the search for a new one. The high levels of unemployment amongst older workers have raised concerns about the sustainability of economic growth, the future availability of skills and labour, and the growing pressures that will be placed on existing pension systems (Ichino et al. 2006). In an effort to encourage the retention of mid and late-career workers, and to reduce the strain on pension systems many developed nations (e.g. New Zealand, Australia, UK, Canada) have abolished compulsory retirement, and increased the age of eligibility for superannuation.

However, as Ichino et al (2006) note, these measures will only help solve pension problems if the employment prospects of mature-aged workers remain intact. This statement is based on evidence indicating that departure from the labour market is not always the result of voluntary retirement, but rather, involuntary exit which results from the various barriers older workers experience in the labour force or when trying to re-enter the labour force (ILO, 1999; Ilmarinen and Rantanen, 1999; DOL, 2002). For instance, a report produced by the International Labour Organisation (1999) suggests older workers (55 years and over) have the highest rates of long-term unemployment, more so than prime age or young workers. Other reports (e.g. Business Council of Australia, 2003; Encel, 2003) highlight the various forms of age discrimination experienced by mature-aged workers in the selection and recruitment process, which effectively reduces their employability.

Similar findings have been substantiated in the New Zealand context. For instance, in their research, McGregor and Gray (2002) found that those in the 45 years and over age groups had a 50:50 chance of never succeeding in finding employment. This is a concern given that firstly, work is sought by these workers moreso for financial reasons than anything else, and secondly, that access to superannuation often remains 10 to 15 years away for some workers (McGregor and Gray, 2002). Difficulties in re-entering the labour force persist despite workers in these age groups being as vigorous in their job search efforts as those in any other age groups, particularly in the first six months. After the first six months, mature-aged job-seekers tend to become increasingly discouraged, feeling more frustrated, insecure and depressed at diminishing work prospects (ibid).

The Work and Age Report (2006) commissioned by the EEO Trust found several forms of discrimination in the selection stage. Participants in this study stated they were often by-passed for jobs as employers preferred younger workers in order to preserve a 'young culture' and 'youthful corporate image'. Respondents stated they had more success with gaining interviews when leaving their age off their CV's, although they rarely made it past the interview stage, where more overt forms of discrimination would set in.
Discrimination continues even when employed. The EEO Trust Report (2006) suggests mature aged workers are often overlooked when opportunities for promotion and/or training and development arise. They also experience negative attitudes in the workplace, for example, being referred to as 'dinosaurs', being thought of as being inflexible, and considered too old to learn new skills or to contribute valuable ideas. Older workers are also more likely than other age groups to be demoted, made redundant and isolated and left out of social activities.

The key barrier faced by mature aged workers both in the job search process, and whilst participating in the labour market, is that of ageism, which manifests as commonly held misconceptions, myths and assumptions about what mature-aged individuals are or are not capable of (HRC, 1999). The HRC (1999) suggest some of the common myths, which have largely been disproved by research, include the belief that as workers age, their abilities and levels of performance decline; that older workers have more absences from work and more accidents than younger workers; that older workers have memory problems, declining intelligence and are less mentally alert; that older workers cannot adapt to new technology; that older workers cost more in the form of remuneration; and finally, that they do not fit into the younger workforce.

The question that remains to be addressed is what types of jobs do mature aged workers find themselves in once they do in fact re-enter the labour force? There is a lack of case study research delving into the experiences of mature aged workers once they do in fact find employment. Moreover, as the literature has shown, mature-aged workers may be victim to ageism and may find their options are increasingly limited. So what alternative remains for those who need to work to meet their financial obligations, but are unable to find quality work?

The findings from the following case study suggest some mature-aged workers are being pushed into low quality and precarious forms of work because of the lack of job opportunities elsewhere. Cranford et al. (2003:3) define as precariousness as a concept that encompasses all those forms of employment that involve: "atypical contracts, limited social benefits and statutory entitlements, job insecurity, low job tenure, low earnings, poor working conditions and high risks of ill health".

Call centres have emerged as a new form of work organisation where precarious working conditions are rampant. Although these organisations offer businesses a new and often more cost effective means of managing customer relations, some call centres experience very high turnover. Turnover can be associated with the intensive labour processes in these organisations. Operators often experience continuous work flow, with calls continuously dropping in throughout the work shift (Fernie and Metcalf, 1997; Crome, 1998; Taylor and Bain, 1999). The work can be emotionally demanding and stressful (Hochschild, 1983) and there is systematic 
monitoring of work performance. The management style is also considered quite coercive - employees experience high degrees of control over how they do their work, as organisations try to maximise the quantity of calls that are processed. Generally, people management practices are not considered strength in these workplaces (Wallace et al. 2002).

Before the accounts of mature-aged workers are examined in the call centre Tadco, the methodology underlying this study will first be outlined (URCOT, 2000).

\section{Research Design}

A qualitative case study methodology was considered the most appropriate for examining the individual experiences of mature aged workers, as it caters for the multiplicity of "reality" captured through subjective experiences, and allows for examination of the experiences of mature-aged workers in the context in which they occur (Ackroyd and Hughes, 1981). Given that this study focussed on the experiences of matureaged workers in their current jobs, both individual and organisational levels of analysis were conducted.

Face-to-face interviews were the primary data collection tool. given the flexibility and vast amounts of information that can be secured through their use (Nachmias and Nachmias, 1996). A semi-structured interview approach allowed the researcher to use general topies to give interviews some degree of direction, and at the same time, considerable flexibility and freedom to clarify questions, explore areas of interest and probe for more information when required (ibid). With minimum direction, the ten respondents had the opportunity to draw attention to issues significant to their experiences, allowing the most salient topics and concerns to emerge (Ackroyd and Hughes, 1981: Nachmias and Nachmias. 1996). An interview schedule was used consisting of general headings, structured as questions that related to various aspects of the employment context. The topics included job content; working hours, employment benefits and entitlements; and Occupational Safety and Health.

\section{Organisational Profile}

As Table 1 below indicates, Tadeo is a well established in-house call centre, with 168 call centre seats. The call centre has been in operation for 38 years - the nature of the services provided make Tadeo a monopoly in the New Zealand marketplace. The work within Tadeo is inbound. with staff receiving calls through their head-sets from an automated queuing system. Employees deal with customer queries and directly modify account information displayed on the PC. using an organisation specific keyboard. The work itself requires minimal skill and offers no variety beyond the phone work. Most of the calls are under 30 seconds, and relate to one of three types of queries or services, each of which has standardised responses and processes. Training needs are therefore minimal. The call centre services calls from existing customers in New Zealand and Australia. The industry in which Tadco operates is relatively stable presenting little competitive pressure. In terms of operating hours, the call centre operates seven days a week. All employees are required to work on Saturdays as a job requirement. Evening work is also regularly required of employees particularly with the expansion into the Australian market.

Table 1: Organisational features of Tadco.

\begin{tabular}{|l|l|}
\hline & \multicolumn{1}{|c|}{ Tadco } \\
\hline Industry & Stable, little competitive pressure \\
\hline Structure & In-house \\
\hline Age & 38 years \\
\hline Size & 160 Seats/ pool of 177 workers \\
\hline Work Function & Customer service \\
\hline Pay Rates & \$13.42 p/h \\
\hline Gender Ratios & Male: $22 \%$ Female: $78 \%$ \\
\hline Union Presence & $\begin{array}{l}105 \text { staff members }(59 \%) \\
\text { unionised by SFWU }\end{array}$ \\
\hline Turnover & $<10 \%$ \\
\hline
\end{tabular}

Tadco prefers middle aged women, and mature-aged workers for call centre positions. Some $31 \%$ of the workforce is over the age of 50 years. Employees are paid $\$ 13.42$ per hour, which is below the average for the New Zealand call centre market, recorded by ACA (2002) at $\$ 15.40$ per hour. Because of the types of employees that are recruited, turnover rates are low when compared with the rest of the New Zealand call centre market (ACA. $2002-18 \%$ in New Zealand). The highest turnover rates are amongst students who move on after completion of their studies. Middle-aged women and mature-aged workers on the other hand, have strong staying power. The Service and Food Workers Union have a relatively strong presence within this organisation, representing $60 \%$ of the staff.

Table 2: Interviewee profiles.

\begin{tabular}{|l|l|l|l|}
\hline Interviewee & Age & $\begin{array}{l}\text { Years } \\
\text { employed } \\
\text { in Tadco }\end{array}$ & Previous Job \\
\hline Lucy & 56 & 8.5 & Legal Secretary \\
\hline Rhonda & 57 & 9.0 & Accounting Clerk \\
\hline Catherine & 57 & 7.25 & Claims Officer \\
\hline Kate & 58 & 5.0 & Copywriter \\
\hline Jane & 60 & 10.0 & Insurance Officer \\
\hline Jack & 60 & 7.0 & Self-employed \\
\hline Mary & 61 & 12.0 & Dealer's Assistant \\
\hline Neil & 64 & 7.0 & $\begin{array}{l}\text { Car Sales } \\
\text { Representative }\end{array}$ \\
\hline Brian & 66 & 13.0 & Inventory Officer \\
\hline Eleanor & 68 & 18.0 & $\begin{array}{l}\text { Local } \\
\text { Government Clerk }\end{array}$ \\
\hline
\end{tabular}

Note: These are fictitious names 
As Table 2 illustrates, all ten interviewees were aged 56 years of age and over at the time of this study. Six of these interviewees were in their 60 's, and seven of the ten were female. The longest tenure from the group was thirteen years; the shortest was five years. As the fourth column indicates, none of the ten interviewees had previous work experience in a call centre environment. All bar two (Jack and Brian) however, previously had careers in white-collar occupations. Out of the ten interviewees, only Lucy and Eleanor had any formal qualifications. During interviews, all ten interviewees stated they had sought work in the call centre for financial reasons, and depended on the income.

\section{Findings}

\section{Job Content}

All ten workers had very low levels of satisfaction with the functional aspects of the job. The work was referred to as "mundane", "boring", "monotonous" and "repetitive". There was constant reference to the work being "low-skilled", with employees and supervisors" indicating they felt there was little to learn through this occupation given the simple and standardised nature of the work.

"The work is not exactly rocket science". (Catherine)

All ten of the mature-aged workers interviewed felt the previous skills and work experiences they brought into Tadco were not fully utilised. Workers felt they had taken a step backwards, but again, had no choice because of the difficulties finding employment that made use of their skills.

\section{"This job was definitely like a demotion or a step down from what I did before. I know it was a long time ago, but back then I had a lot more responsibility. like I felt what I was doing was important. The way it is now I feel there's so much I could do but can't. I mean what more is there to do here really?" (Catherine)}

Despite the low-skill requirements of this job, four workers showed an interest in receiving training and the opportunity to up-skill, particularly in customer services skills. These employees were however adamant that the organisation would not provide the training they were interested in receiving.

"It's not really something they do in this organisation; we re just here to do the job. there are no extras". (Brian)

Little effort was made by managers to improve job variety. The pace of call did however vary. During peak times, the pace of work becomes intense, with a quick succession of calls dropping in. During these times the calls were found to create "too much tension and pressure".
"You're speaking to about 100 people in less than 40 minutes, so you have someone talking in your ear in your ear every 30 seconds, you're constantly talking". (Rhonda)

Three workers drew parallels between their work and the production line work in factory environments. These individuals stated they experienced limited control and autonomy in respect to when and how to take calls particularly with the automatic call routing system, and the standardised responses and processes established to ensure consistency in service delivery.

\section{"I always liken it to as a factory - I consider us to be sort of as the factory workers". (Jack)}

Eight of the ten mature-aged workers felt little attachment to the work or the organisation, and openly referred to their work and occupation as holding a low social status.

\section{"We are not the great of the great, we're the last off the ship". (Catherine)}

These workers referred to the coercive and controlling management style used. Most found the experience of being monitored by supervisors as condescending and demoralising, particularly given their many years of prior work experience.

\section{"We're the peasants and they (the management) are the landowners". (Neil)}

These feelings could be associated with a growing sense of resentment amongst these workers. Three of the interviewees openly declared their resentment for management and the organization. There was unanimous agreement by the interviewees that this work was not the type of work they would typically choose to do. Although considerably dissatisfied with the features of the job, most felt they had no other choice but to work in these environments as they felt they were "too old" or "too under qualified" to get jobs elsewhere. This was based on their experiences as mature-aged job seekers.

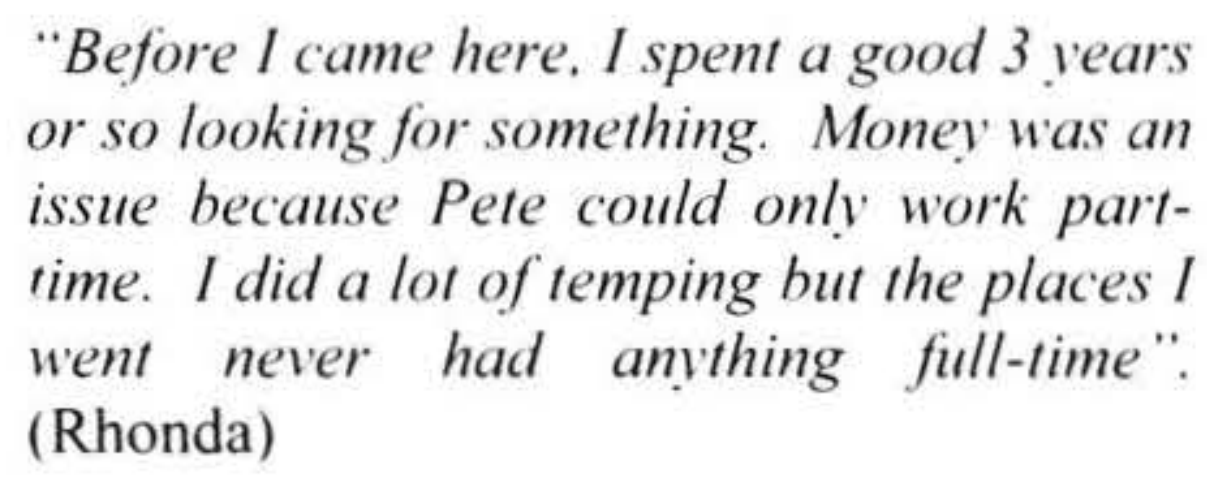

Similarly, all those interviewed stated they would move to another job if the opportunity arose, although this was considered "highly unlikely". The lack of opportunities elsewhere therefore lead these workers to feel they could not "afford to be choosy" about where they work. Most were "just grateful to have a job", and thus, the only attractive aspect of the job for the majority of these workers was the fact that it was $a$ job.

"When I lost my job seven or so vears ago I
bloody applied and door knocked 
everywhere. No-one had any use for me. I came here because they took me - no other reason". (Neil)

"At this stage of my life it doesn't pay to be picky". (Kate)

\section{Working Hours}

All ten of the mature-aged workers stated they were unhappy about having to work on weekends as a job requirement. Saturday work was identified as particularly disruptive with these employees stating it interfered with valuable family time, and social activities.

"I'm not satisfied in the weekend, because I can't see my grandchildren, and I should be able to". (Eleanor)

Four of these workers also stated they were often rostered on for six days a week, which actually prevented them from participating in non-work activities.

\section{"To be really blunt, there's 7 davs in a week and I'm here for 6 of them. what social life?" (Kate)}

The absence of penal rates on evenings, Saturdays and Sundays was identified as one of the greatest causes of dissatisfaction for mature-aged workers in Tadco. However, given that these mature-aged workers relied on their employment in Tadco as a sole source of income and felt it was unlikely they would find work elsewhere given their age, most felt there was little choice but to accept the situation.

"I've just accepted it because if I don't have the income coming in I can't pay for what I have to". (Mary)

\section{Benefits and Entitlements}

All ten of the mature-aged workers in Tadco expressed a significant amount of dissatisfaction at the lack of access to a superannuation scheme, particularly given the length of time they had served in the organisation.

\begin{abstract}
"The ladies in there between 55-65 couldn't get a job am where else, there should be a super scheme. We have ladies who have worked here for more than 25 rears, and if they walked out the company would give them absolutely nothing". (Jack)
\end{abstract}

In addition, these workers raised the need for ongoing. performance related reward systems. Four individuals stated they often felt undervalued in the organisation, and felt their efforts were often not appreciated. Furthermore, they claimed there was little incentive for them to perform, and thus, emphasised performance related reward systems as a means of boosting their motivation levels. The absence of penal rates (as outlined earlier) was also emphasised as a cause of dissatisfaction.

\begin{abstract}
"Some days we 're working quite hard and we don't get appreciation for it I'm sure...things like incentives come and go, they're not ongoing". (Mary)
\end{abstract}

\section{Occupational Health and Safety}

When questioned about the Occupational Health and Safety issues experienced in the workplace, all ten of the interviewees indicated they felt the working environment did not meet their Occupational Health and Safety needs. All of the interviewees stated they regularly encountered abusive and disgruntled customers over the phone, and stated the organisation had few mechanisms to support their needs as employees when such incidences occurred. Given the regularity of the occurrence, dealing with difficult customers was largely considered just 'another part of the job".

\section{"It's just the nature of the work, you just get on with it". (Eleanor)}

Three of these workers however, stated the abuse had left them feeling upset, distraught, and demoralised.
"It's pretty tough sometimes; you have idiots call up that swear at you. That gets to me. Sometimes I go home feeling pretty down". (Jane)

The nature of the work was also associated with physical health issues. Four mature-aged workers noted that sitting for long periods of time left them with muscular aches.

\section{"Physically it's bad for the back, the chairs and sitting there for six hours. In six hours we only get two ten minute breaks and one 15 minute break". (Mary)}

Another employee complained of severe ear aches, headaches and hearing loss. This worker stated that despite the severity of his condition, the organisation had failed to take his complaints seriously. Without first conducting an investigation, the organisation attributed his health problems to his age.

\section{"They didn't even check the phones before telling me it wasn't the phones causing it. Thev treated me like a fool saving oh well - it 's something that comes with age". (Neil)}

The organisation also issued warnings to this worker when he attempted to take time off to recuperate. Measures were only taken once several doctors' reports were produced.

"The doctors said I had tinnitus from the high decibel frequency of the headsets. They only investigated after I showed the managers the reports. Even then it took them a while to finally put soundshields on my headset. The damage had already been done". (Neil) 


\section{Discussion}

A recurrent theme in the above case study is the feeling amongst mature-aged workers that they are forced to participate in low quality work because of the lack of opportunities elsewhere. Although the call centre market in New Zealand is marked by significant diversity, Tadco represents what would largely be considered a low-end call centre characterised by low skilled-low pay work, and little in the way of investment in human resources. As the above findings illustrate, little effort is made on the part of the organisation to modify the working environment and to introduce policies and initiatives to improve levels of morale and job satisfaction.

In fact, it appears to be the case that such initiatives are largely unnecessary given the type of call centre we are dealing with. Specifically, Tadco is a monopoly in the marketplace and therefore experiences no direct competition. Furthermore, the nature of the work is considered low-skilled, meaning workers can be easily replaced if necessary. Some parallels can be drawn between the human resource strategy used in this call centre, and what Wallace et al. (2002) describe as "the sacrificial HR strategy" used in many call centres. This strategy is based on a deliberate, frequent replacement of employees; the key motive being that there are always enthusiastic and motivated customer service staff in the front-line at low cost to the organization. The costs of people management and employee development are minimised because rather than invest in initiatives to improve levels of morale and commitment, stressed and burnt out employees are simply replaced with a fresh batch of recruits (Wallace et al. 2002).

Tadco however, differs slightly in their approach. Given the organisations monopoly status, happy and motivated workers are not considered a necessity. The only priority is to ensure that there are enough workers available to service calls. The key concern is the need to have a committed workforce; committed in the sense that they will turn up to work, and will stay in the organisation for a long period of time. This further minimises costs by minimising the need to replace workers. Tadco achieves this through a deliberate strategy to target those who are likely to have the strongest reliance on the work, and thus, have the longest staying power, i.e. middle aged women and mature-aged workers. The approach is sacrificial in that low levels of job satisfaction and low morale are tolerated and accepted, because as mature aged workers - these individuals are unlikely to go elsewhere.

The vulnerability of these mature-aged workers is secured in two ways: firstly, by their financial situations, and the need to work simply to sustain an adequate standard of living; and secondly, by the increasingly levels of ageism present in the marketplace, which sees mature-aged workers largely cast aside to make room for younger recruits. In fact, it is the case that for the mature-aged workers in this study, commitment is largely a product of the paucity of work opportunities elsewhere. These workers are reluctant participants forced into this work environment out of necessity and financial hardship rather than any particular attraction to the work or the industry itself. The result is the emergence of a sub-culture of low morale, dithering motivation and increasing levels of resentment.

Difficulties in regulating these types of managerial practices further exacerbate these issues. Looking into the future, economies across the industrialised world will rely more heavily on mature-aged workers to fill the skills and labour deficits that are likely to result from the ageing of the population (Ilmarinen, 1999; Seitsamo and Illmarinen, 1997; Business Council of Australia, 2003). Because of this increased dependence on their skills, a more promising future may in fact be a reality for workers who will fall into the 50 years and over age groups in the coming decades. Nevertheless, the experiences of mature-aged workers in the current economic environment is an equally, if not more significant concern, particularly those experiencing deprivation due to exploitative managerial strategies.

\section{Future Research}

As mentioned earlier, given the limited scope of this study, the findings cannot be generalised to the matureaged population as a whole. Nevertheless, this paper does raise questions surrounding the labour market status and experiences of workers in these older age groups. More in depth case study research across a wider range of industries is, however, necessary to examine whether these types of experiences are typical amongst the mature-aged workforce. In particular, there needs to be greater exploration into the issue of ageism and the impact it has on the employment choices of these workers.

\section{References}

Ackroyd, S., and Hughes, J. (1981). Aspects of Modern Sociology: Data Collection in Context, USA: Longman.

Business Council of Australia (2003). A Business Guide for Supporting Older Workers, online: http://www. bca.com.au/content.asp?Newsid $=9172$ 0 , accessed 01/10/2006.

Commonwealth of Australia (2002). National Strategy for an Ageing Australia: An Older Australia. Challenges and Opportunities for all. Issued by the Hon. Kevin Andrews, MP, Minister for Ageing, Canberra, 2001, reprinted with amendments 2002 .

Cranford, C., Vosko, L., and Zukewich, N. (2003). The Gender of Precarious Employment in Canada. Industrial Relations, Fall Issue.

Crome, M. (1998). Call centres: Battery farming or free range. Industrial and Commercial Training, 30(4), 137-145. 
Department of Labour (2002). Population Ageing: Where Will it Take us? Online: http://www.dol.govt.nz /futureofwork/workforce-ageing.asp, accessed 01/10/2006.

Department of Economic and Social Affairs (2003). World Population Ageing: 1950-2050, United Nations, online :http://www.un.org/esa/population/publications /worldageing 19502050/, accessed 12/10/2006.

Encel, S. (2003). Age Can Work: The Case for Older Australians Staning in the Workforce. A Report to the Australian Council of Trade Unions and the Business Council of Australia, Social Policy Research Centre. University of NSW.

EEO Trust (2006). EEO Work and Age Surver Report. http:/www.eeotrust.org.nz/research/index.cfim

Hoschild. A. (1983). The Managed Heart: The Commercialisation of Human Feeling. Berkeley, CA: University of Califomia Press.

Human Rights Commission (1999). Age and Retirement in the Public Senvice Legal and Human Resource Implications of the Aholition of Compulson Retirement. State Services Commission, http:/www.ssc.govt.nz upload/downloadable_files/Age_and_Retirement.pdf, accessed 12/10/06.

Ichino, A., Schwerdt, G., Winter-Ebmer, R. and Zweim uller, J. (2006). Too Old to Work, Too Young to Retire? European University Institute, http://www iue.it Personal/lchino/ichino__old 12.pdf, accessed 20/10/06.

Ilmarinen, J. and Rantanen, J. (1999). Promotion of work ability during ageing'. American Joumal of Industrial Mecdicine, Sept. 21-3.

Ilmarinen, J. (1999). Ageing Workers and the European Union - Status and Promotion of Work thilin: Emplosahilits and Emploimen. Finnish Institute of Occupational Health. Helsinki.

International Labour Organization ( 1999). Horld Emploıment Repor\%, Online: http://www.ilo.org/public spanish/region/ampro/cinterfor/ret/34rct/doc/employ wer98ch6.htm, accessed 20/10/06.

Lissenburgh, S. and Smeaton, D. (2003). Emplosment Trunsitions of Older Workers: The Role of Flexible Emplorment in Maintuining Lahour. Market Participation and Promoting Joh Qualit: The Policy Press: UK.

Ministry of Social Policy (2001). The New Zealund Positive Ageing Strategr; http://www.osc.govt.nz/documents nzpositiveageingstrategy.pdf, accessed 11/10/2006.

McGregor, J. and Gray, L. (2002). Older Joh Seekers at Risk of Long-Term Unemplorment, http://masseynews .massey.ac.nz/magazine/2002 April/stories/research develop.html, accessed 13/10/06.

McGregor, J. (2006) Age will work: Progressing the case for older workers in the New Zealand workforce. Introductory Paper for the Employment of Older Worker Summit, September 4, 2006,

http://www.retirement.org.nz/files/Age_will work.pdf, accessed 20/10/06.

Nachmias, C., and Nachmias, D. (2000). Research Methods in the Social Sciences. $6^{\text {th }}$ edition, London: Worth.

Richardson, R., and Marshall, J. (1999). Teleservices, call centres and urban and regional development. The Service Inchustries Journal, 19(1), 96-117.

Paul, J., and Huws, U. (2002). How Can We Help? Good Practice in Call Centre Employment. Second Draft Report for the TOSCA Project. Analytical Social and Economic Research Ltd.

Seitsamo, J. and Illmarinen, J. (1997), Life-style, ageing and work ability among active Finnish workers in 19811992. Scandinavian Journal of Work, Environment and Health, 23(1), 20-26.

Sjoberg, G., Williams, N., Vaughn, T. and Sjoberg, A. (1991). The case study approach in social research: Basic methodological issues. In Feagin et al (eds.). $A$ Case for the Case Stuctn. NC: The University of North Carolina Press.

Statistics New Zealand (2001). Census of Population and Divellings. http://www.stats.govt.nz accessed: 03/05/04.

Statistics New Zealand (2004). Population Ageing in New Zealand, http://www.stats.govt.nz, accessed 10/09/06.

Taylor, B., and Bain, P. (1999). An 'assembly line in the head': Work and employee relations in the call centre. Industrial Relations Journal, 30(2), 101-117.

Wallace, C., Eagleson, G. and Waldersee, R. (2000). The Sacrificial HR strategy in call centres. International Joumal of Senvice Industry Management, 11(2), 174.

World Health Organization (1993). Aging and Working Capacit: Report of a WHO Stuch Group. Geneva: WHO technical report series, no 835 .

\section{Author}

Zeenobiyah Hannif

Associate Lecturer

School of Management and Marketing

University of Wollongong

Wollongong

NSW 2522

Australia

zennie (auow.edu.au 